\title{
Development of key soil health indicators for the Australian banana industry
}

\author{
A.B. Pattison ${ }^{a, *}$, P.W. Moody ${ }^{b}$, K.A. Badcock ${ }^{a}$, L.J. Smith ${ }^{d}$, J.A. Armour ${ }^{c}$, \\ V. Rasiah ${ }^{\text {c }}$, J.A. Cobon ${ }^{d}$, L.-M. Gulino ${ }^{d}$, R. Mayer ${ }^{e}$ \\ ${ }^{a}$ Department of Primary Industries \& Fisheries, PO Box 20, South Johnstone, Qld 4859, Australia \\ ${ }^{\mathrm{b}}$ Department of Natural Resources and Water, 80 Meiers Road, Indooroopilly, Qld 4068, Australia \\ ${ }^{\mathrm{c}}$ Department of Natural Resources and Water, 28 Peters Street, Mareeba, Qld 4880, Australia \\ ${ }^{\mathrm{d}}$ Department of Primary Industries \& Fisheries, 80 Meiers Road, Indooroopilly, Qld 4068, Australia \\ ${ }^{\mathrm{e}}$ Department of Primary Industries \& Fisheries, PO Box 1085, Townsuille, Qld, 4810, Australia
}

\section{A R T I C L E I N F O}

Article history:

Received 18 May 2006

Received in revised form

3 April 2008

Accepted 7 April 2008

\section{Keywords:}

Agroecosystems

Bioindicators

Biological soil indicators

Chemical soil indicators

Musa AAA

Physical soil indicators

Soil carbon

Soil nematode community

composition

Soil management

\begin{abstract}
A B S T R A C T
To improve the sustainability and environmental accountability of the banana industry there is a need to develop a set of soil health indicators that integrate physical, chemical and biological soil properties. These indicators would allow banana growers, extension and research workers to improve soil health management practices. To determine changes in soil properties due to the cultivation of bananas, a paired site survey was conducted comparing soil properties under conventional banana systems to less intensively managed vegetation systems, such as pastures and forest. Measurements were made on physical, chemical and biological soil properties at seven locations in tropical and sub-tropical banana producing areas. Soil nematode community composition was used as a bioindicator of the biological properties of the soil. Soils under conventional banana production tended to have a greater soil bulk density, with less soil organic carbon (C) (both total C and labile C), greater exchangeable cations, higher extractable $\mathrm{P}$, greater numbers of plant-parasitic nematodes and less nematode diversity, relative to less intensively managed plant systems. The organic banana production systems at two locations had greater labile C, relative to conventional banana systems, but there was no significant change in nematode community composition. There were significant interactions between physical, chemical and nematode community measurements in the soil, particularly with soil C measurements, confirming the need for a holistic set of indicators to aid soil management. There was no single indicator of soil health for the Australian banana industry, but a set of soil health indicators, which would allow the measurement of soil improvements should include: bulk density, soil C, pH, EC, total N, extractable P, ECEC and soil nematode community structure.
\end{abstract}

Crown Copyright (C) 2008 Published by Elsevier B.V. All rights reserved.

\section{Introduction}

The Australian banana industry produces approximately 350,000 tonnes of fruit annually, all of which is sold on the domestic market. The industry is comprised of two compo- nents: a subtropical industry based in northern New South Wales, south-east Queensland and around Carnarvon in Western Australia, and a tropical component located around Kununurra in Western Australia, Darwin in the Northern Territory and the increasingly important wet tropics region of

\footnotetext{
* Corresponding author. Tel.: +61 74064 1130; fax: +61 740642249.

E-mail address: Tony.Pattison@dpi.qld.gov.au (A.B. Pattison).

0929-1393/\$ - see front matter. Crown Copyright (C) 2008 Published by Elsevier B.V. All rights reserved. doi:10.1016/j.apsoil.2008.04.002
} 
north Queensland, where $88 \%$ of the country's bananas are produced (Collins et al., 2004). However, the tropical banana industry in Queensland was identified as a contributor to nutrients and sediments in waterways and the Great Barrier Reef lagoon (Anon., 2003; Kleiese et al., 1997; Moody and Aitken, 1997). To reduce the impact of the banana industry on the environment, investigations into soil health and sustainability have been given a high priority by the industry.

For the banana industry to improve soil management there is a need to develop a set of indicators that are able to quantify changes in soil properties and which can promote improved land management practices. These indicators should encompass a holistic view of soil management. Indicators should not be limited to crop productivity, but should account for changes in the physical, chemical and biological properties of the soil (Karlen et al., 2003). Historically, banana grower's measure soil fertility as part of their nutrient management programme, but there is little known about soil physical properties and even less known about the biological status of the soil, apart from the presence of pathogens. Similarly, there is little information available on the interaction between the chemical, physical and biological properties in banana-growing soils. It has been suggested that knowledge of the soil ecosystem is a basic requirement to soil stewardship and, accordingly, national and regional programs have been established to monitor soil health or quality (Lilburne et al., 2004; Neilsen and Winding, 2002). However, many programs develop broad concepts that are difficult to implement at an industry or farm level for quantifying practice change; more specific soil indicators are needed to monitor changes in soil management (Andrews et al., 2004; Glover et al., 2000; Neher, 1999a,b). The establishment of soil health indicators requires comparison with reference sites to be able to establish thresholds where soils are not as disturbed, such as pastures and forests (Neher and Campbell, 1994; Neher et al., 2005).

The selection of soil health indicators should follow the principles suggested by Doran and Safley (1997). In particular, the indicators should be sensitive to changes due to soil management, work in a wide range of environments and integrate soil physical, chemical and biological properties (Doran and Safley, 1997). There is a tendency, in the development of soil health indicators, to attempt to measure everything, but this is time consuming, laborious and expensive (Sanchez et al., 2003). Instead, there should be a minimum set of soil health indicators that are related to soil functions and that facilitate improvements in soil health management (Andrews et al., 2004; Karlen et al., 2003).

Soil dwelling nematodes have been promoted as effective bioindicators of soil health due to their ability to respond to changes in the soil physical and chemical environment (Coleman et al., 2004; Neher, 2001; Schloter et al., 2003). The classification of soil nematodes into trophic groups can be used as a surrogate measurement for microbial composition in the soil. An understanding of nematode life strategies, whether colonisers or persisters ( $c-p)$, can provide information about the level of disturbance in the soil environment (Bongers, 1990). Furthermore, there have been a number of advances in the interpretation of the nematode community composition that enable changes in the nematode community structure to be related to changes in the soil environment
(Bongers, 1990; Ferris et al., 2001; Gupta and Yeates, 1997; Yeates and Bongers, 1999).

It was the aim of the survey described here to determine how soil chemical, physical and biological properties have changed due to land management under conventional banana production, using a range of field and laboratory indicators. The most sensitive, practical and reliable measurements were then used to make a minimum data set of soil health indicators. The soil health indicators can be used by aid the banana industry to make informed land management decisions and provide a basis for further research and extension activities for improving soil management.

\section{Materials and methods}

\subsection{Survey sites}

Paired site surveys were conducted between March and September 2003 to investigate soil properties under four conventional banana fields in the tropical banana production area of north Queensland and three fields in the sub-tropical banana production area of south-east Queensland (Table 1). The sites represented the major regions and soil types used for banana production in eastern Australia. The sites were also selected for their ability to compare soil properties under banana cultivation with less intensively managed vegetation systems (pasture or forest) and different banana management systems: organic and conventional banana production (Table 1). Sites at East Palmerston, Mission Beach and Terranora were Ferrosols (Isbell, 1996) of volcanic origin, whereas the Tully, Kennedy and Nambour sites comprised Dermosols (Isbell, 1996) of alluvial origin. The Wamuran soil was a Podosol (Isbell, 1996). All sites had been growing bananas for greater than 4 years, except for a newly planted banana field at Wamuran (plant banana). The forest and pasture sites had not been mechanically disturbed for greater than 10 years.

\subsection{Sampling method}

Four replicate soil cores were taken from each plant system at each location, using a hydraulic $50 \mathrm{~mm}$ diameter soil corer or a $100 \mathrm{~mm}$ diameter hand auger. Samples were collected at depth intervals 0-10, 10-20, 20-30, 30-50, 50-70 and 70-90 cm. For the banana system, four profiles, no more than $10 \mathrm{~m}$ apart, were sampled in each of two adjacent rows, with samples taken $30 \mathrm{~cm}$ from the base of the banana plant. Soil samples in the undeveloped systems were taken at random intervals along the same contour as the banana soil samples, and no further than $100 \mathrm{~m}$ from the banana area. Samples were stored in cooled foam boxes for transport to the laboratory. Subsamples, $200 \mathrm{~g}$ each, were immediately extracted in a field moist state for mineral $\mathrm{N}$ and nematode analysis to avoid changes due to drying and storage.

\subsection{Physical soil measurements}

The silt and clay contents of the samples were determined by the hydrometer method following chemical dispersion (Rayment and Higginson, 1992). At the three sites in north 
Table 1 - Location, rainfall and soil types of paired sites comparing conventional banana production to less intensively managed vegetation systems to determine key soil indicators

\begin{tabular}{|c|c|c|c|c|c|}
\hline Location & Longitude (E) & Latitude (S) & Annual rainfall (mm) & Soil type (Isbell, 1996) & Plant system \\
\hline East Palmerston & $145^{\circ} 50^{\prime} 25^{\prime \prime}$ & $17^{\circ} 36^{\prime} 30^{\prime \prime}$ & 3627 & Ferrosol & $\begin{array}{l}\text { Bananas } \\
\text { Pasture }\end{array}$ \\
\hline Mission Beach & $146^{\circ} 5^{\prime} 18^{\prime \prime}$ & $17^{\circ} 51^{\prime} 32^{\prime \prime}$ & 2739 & Ferrosol & $\begin{array}{l}\text { Banana } \\
\text { Organic banana } \\
\text { Forest }\end{array}$ \\
\hline Tully & $145^{\circ} 47^{\prime} 26^{\prime \prime}$ & $17^{\circ} 54^{\prime} 51^{\prime \prime}$ & 4118 & Dermosol & $\begin{array}{l}\text { Bananas } \\
\text { Pasture } \\
\text { Forest }\end{array}$ \\
\hline Kennedy & $145^{\circ} 55^{\prime} 2^{\prime \prime}$ & $18^{\circ} 12^{\prime} 15^{\prime \prime}$ & 2239 & Dermosol & $\begin{array}{l}\text { Bananas } \\
\text { Forest }\end{array}$ \\
\hline Nambour & $152^{\circ} 55^{\prime} 12^{\prime \prime}$ & $26^{\circ} 37^{\prime} 49^{\prime \prime}$ & 1709 & Dermosol & $\begin{array}{l}\text { Bananas } \\
\text { Pasture }\end{array}$ \\
\hline Terranora & $153^{\circ} 30^{\prime} 1^{\prime \prime}$ & $28^{\circ} 14^{\prime} 0^{\prime \prime}$ & 1720 & Ferrosol & $\begin{array}{l}\text { Bananas } \\
\text { Forest }\end{array}$ \\
\hline Wamuran & $152^{\circ} 51^{\prime} 43^{\prime \prime}$ & $27^{\circ} 2^{\prime} 30^{\prime \prime}$ & 1846 & Podosol & $\begin{array}{l}\text { Organic } \\
\text { Plant bananas } \\
\text { Pasture }\end{array}$ \\
\hline
\end{tabular}

Queensland (Mission Beach, Tully and Kennedy), soil bulk density was determined to a depth of $20 \mathrm{~cm}$ in close proximity to where the core samples had been taken from one of the banana rows. The procedure was repeated in the nearby forest, again with samples taken in close proximity to the core sampling locations. At the Mission Beach site, bulk density under conventional banana production was compared to that under organic banana management and under forest. At Tully and Kennedy, bulk density was compared between conventional banana production and forest soil. Soil bulk density was measured at $5 \mathrm{~cm}$ depth increments to a depth of $20 \mathrm{~cm}$ using a hand pushed metal corer $(72 \mathrm{~mm} \mathrm{~d} \times 50 \mathrm{~mm})$. The procedure was replicated four times at each site. The moist soil cores were weighed in the laboratory, oven dried at $105^{\circ} \mathrm{C}$ for $24-36 \mathrm{~h}$ and weighed again to determine oven dry weight. The bulk density was calculated using oven-dry weight and core volume.

\subsection{Chemical soil measurements}

Soil sub-samples collected from the top $10 \mathrm{~cm}$ were air dried at $40{ }^{\circ} \mathrm{C}$ and sieved to $<2 \mathrm{~mm}$. The soil was analysed for $\mathrm{pH}$ (1:5 water and $0.01 \mathrm{M} \mathrm{CaCl}_{2}$ ), electrical conductivity (1:5 water), $\mathrm{pH}$ buffering capacity in $0.002 \mathrm{M} \mathrm{CaCl}_{2}$ (pHBC) (Aitken and Moody, 1994) and exchangeable cations ( $\mathrm{Na}, \mathrm{K}, \mathrm{Ca}$ and $\mathrm{Mg})\left(1 \mathrm{M} \mathrm{NH}_{4} \mathrm{Cl}\right.$, $\mathrm{pH}$ 7.0) using the methods described by Rayment and Higginson (1992). The effective cation exchange capacity (ECEC) was calculated by summing the exchangeable acidity $(\mathrm{Al}+\mathrm{H})$ and the exchangeable cations $(\mathrm{Na}+\mathrm{K}+\mathrm{Ca}+\mathrm{Mg})$. Analysis of total organic $\mathrm{C}$ and total $\mathrm{N}$ were determined using a Leco C-N analyser. Bicarbonate extractable $\mathrm{P}$ was determined using the Colwell (1963) method. Labile organic C oxidisable by $33 \mathrm{mM} \mathrm{KMnO}_{4}$ was determined using the method described by Moody et al. (1997).

\subsection{Biological soil measurements}

Nematodes were extracted from soil by placing $200 \mathrm{~g}$ of field moist soil on a single layer of tissue, contained within a mesh basket (Whitehead and Hemming, 1965). The basket was placed in $200 \mathrm{~mL}$ of water within a tray and maintained at $25^{\circ} \mathrm{C}$. After $48 \mathrm{~h}$, nematodes contained within the water of the tray were collected on a $25 \mu \mathrm{m}$ sieve. The nematodes were backwashed from the sieve and collected in a $30 \mathrm{~mL}$ vial. The total number of nematodes extracted from $200 \mathrm{~g}$ of soil was determined. Using a compound microscope, nematodes were identified to genera for plant-parasitic nematodes or to family for non-parasitic nematodes and assigned to trophic groups according to Yeates et al. (1993).

\subsection{Nematode indices}

Indices of the nematode community composition were calculated from nematodes extracted from the soil. Nematode diversity was determined using the Shannon-Weiner index, $H^{\prime}=-\Sigma p_{i} \log _{e} p_{i}$ and dominance calculated using Simpson's index of dominance, $\lambda=\Sigma\left(p_{i}\right)^{2}$, where $p_{i}$ is the proportion of individuals in the ith taxon (Yeates and Bongers, 1999). The bacterial-fungal ratio was determined using $\mathrm{B}: \mathrm{F}$ ratio $=\mathrm{B} /$ $(B+F)$ where $B$ and $F$ are, respectively, the relative contributions of bacterivorous and fungivorous nematodes to total nematode abundance, which is constrained to values between 1 (totally bacterivore dominated) and 0 (totally fungivore dominated) (Yeates, 2003).

Additionally, the weighted faunal analysis concept was applied, without plant-feeders, to determine the basal, structure and enrichment conditions of the soil food web, as well as the decomposition channel of nutrients (Ferris et al., 2001). The enrichment index (EI) assesses the resources available to the soil food web and response by primary decomposers to those resources. The structure index (SI) is a measure of the number of trophic layers in the soil food web and the potential for regulation by predators. The channel index (CI), is an indication of the decomposition channel of nutrients, where a low value suggests a bacterial decomposer community and a high value indicates a fungal-dominated decomposer nematode community (Ferris et al., 2001; Hohberg, 2003). 


\subsection{Statistics}

Factors in the dataset were unbalanced and, as a result, means from sampling sites were analysed using REML (residual maximum likelihood) and separated with the $\chi^{2}$ test using the statistical package Genstat 5 (Lawes Agricultural Trust). The main effects for the type of plant system (conventional bananas, organic bananas, plant banana, pasture or forest) were used for each location. The variance model derived from the REML analysis was used to calculate least significant differences of means (LSDs) at $P<0.05$. Total nematode numbers and number of nematodes in each trophic group per $100 \mathrm{~g}$ of soil were transformed using $\ln (x+1)$, prior to analyses, to comply with assumptions of normal distribution. Only the back-transformed means are presented in tables. The relationships between silt and clay content of the soil and the number of nematodes in trophic groups were investigated with a multivariate cluster analysis. This allowed the construction of a dendrogram using the group average method to determine the similarity between land use and sampling sites. Sites linked at a Euclidean distance of 0.85 or greater were considered to be in the same group. Correlation coefficients between soil properties were determined using the statistical package Genstat 5 (Lawes Agricultural Trust).

\section{Results}

\subsection{Physical soil measurements}

Similarities in the silt and clay contents of the soil profiles were used to confirm soil type similarities at each paired site. A multivariate cluster analysis dendrogram of the silt and clay content of the soil revealed that five out of the sevenpaired sites (viz. Kennedy, East Palmerston, Tully, Terranora and Wamuran) had silt and clay contents under banana with a $90 \%$ similarity to the undeveloped vegetations (Fig. 1). Therefore, it was assumed that any differences in soil properties at these five sites could be attributed to land use and land management effects on soil properties. However, the rainforest site at Mission Beach and pasture site at Nambour had a similarity less than $77 \%$ to their paired banana sites (Fig. 1). This suggested that there was a change in soil type at Nambour and Mission Beach between the undeveloped sites and the banana sites.

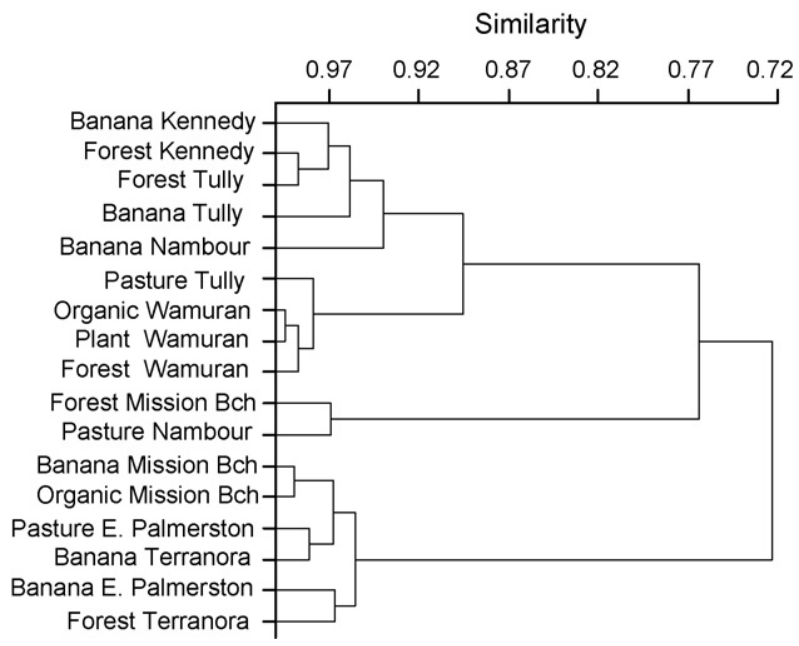

Fig. 1 - Multivariate cluster analysis dendrogram of the similarities of soil profile clay and silt contents at seven locations comparing conventional banana production to less intensively managed vegetation systems.

The mean soil bulk density tended to be higher under bananas than under forest at Kennedy, Mission Beach and Tully (Table 2). The highest mean bulk density to a depth of $20 \mathrm{~cm}$ was recorded in bananas at Tully $\left(1.28 \mathrm{Mg} \mathrm{m}^{-3}\right)$, the lowest mean bulk density to $20 \mathrm{~cm}$ was in forest soil at Kennedy (1.03 $\mathrm{Mg} \mathrm{m}^{-3}$ ) (Table 2). The soil bulk density tended to increase with depth at all sites, except under bananas in Tully and Mission Beach, which remained uniform to $20 \mathrm{~cm}$ (Table 2). The bulk density in the soil was negatively correlated to total C $(r=-0.82, P<0.05)$ labile $C(r=-0.81, P<0.05)$, total $\mathrm{N} \quad(r=-0.80, P<0.05)$ and the number of omnivorous nematodes $(r=-0.72, P<0.05)$ measured across the sites.

\subsection{Chemical soil measurements}

Soil total $\mathrm{C}$ and labile $\mathrm{C}$ were significantly different between the vegetation systems (Fig. 2). The labile $C$ was significantly reduced by half in conventional banana production relative to forest soils and organic bananas (Fig. 2). Similarly, the total C content was higher under the organic banana sites relative to a newly planted banana crop (plant banana), but not significantly greater than conventional bananas (Fig. 2). Total C and

Table 2 - Bulk density to $20 \mathrm{~cm}$ under conventional banana production and corresponding forest sites in north Queensland

\begin{tabular}{|c|c|c|c|c|c|c|c|c|}
\hline \multirow[t]{2}{*}{ Depth $(\mathrm{cm})$} & \multicolumn{2}{|c|}{ Kennedy } & \multicolumn{3}{|c|}{ Mission Beach } & \multicolumn{3}{|c|}{ Tully } \\
\hline & Banana & Forest & Banana & Organic & Forest & Banana & Pasture & Forest \\
\hline \multicolumn{9}{|c|}{ Bulk density $\left(\mathrm{Mg} \mathrm{m}^{-3}\right)$} \\
\hline $0-5$ & $1.18 \mathrm{a}$ & $0.86 \mathrm{a}$ & $1.03 \mathrm{a}$ & $1.04 \mathrm{a}$ & $0.93 \mathrm{a}$ & $1.17 \mathrm{a}$ & - & $1.08 \mathrm{a}$ \\
\hline $5-10$ & $1.26 \mathrm{~b}$ & $1.03 \mathrm{~b}$ & $1.08 \mathrm{a}$ & $1.20 \mathrm{~b}$ & $1.06 \mathrm{~b}$ & $1.26 \mathrm{a}$ & - & $1.13 \mathrm{a}$ \\
\hline $10-15$ & $1.26 \mathrm{~b}$ & $1.00 \mathrm{~b}$ & $1.13 \mathrm{a}$ & $1.17 \mathrm{~b}$ & $1.08 \mathrm{~b}$ & $1.32 \mathrm{a}$ & - & $1.24 \mathrm{~b}$ \\
\hline $15-20$ & $1.19 \mathrm{a}$ & $1.21 \mathrm{c}$ & $1.12 \mathrm{a}$ & $1.24 \mathrm{~b}$ & $1.11 \mathrm{~b}$ & $1.35 \mathrm{a}$ & - & $1.24 \mathrm{~b}$ \\
\hline Mean ( \pm S.E.) & $1.22(0.07)$ & $1.03(0.12)$ & $1.09(0.09)$ & $1.16(0.07)$ & $1.05(0.03)$ & $1.28(0.10)$ & - & $1.18(0.08)$ \\
\hline
\end{tabular}




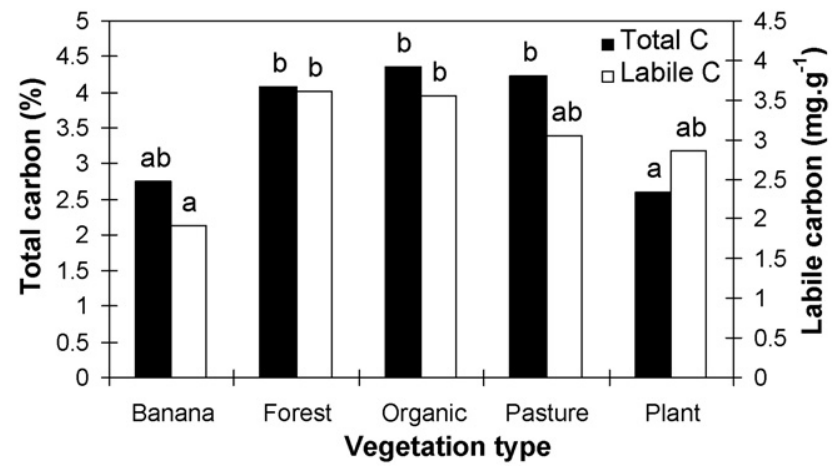

Fig. 2 - Total and labile carbon content of soil from paired sites comparing conventional banana production to less intensively managed vegetation systems (columns with the same shade and subscript above are not significantly different at the $P<0.05$ ).

labile C were positively correlated to each other $(r=0.82$, $P<0.05)$. Additionally, total $C$ was positively correlated with total $\mathrm{N}(r=0.90, \mathrm{P}<0.05)$.

Colwell $\mathrm{P}$ in the top $10 \mathrm{~cm}$ of soil was double or 10 times higher under bananas than under the less developed land uses of pasture or forest, respectively (Table 3). Similarly, the EC and $\mathrm{pHBC}$ tended to be twice as high under bananas relative to the corresponding, less developed paired sites (Table 3). Significant differences in chemical properties were measured between locations, although they were not confined to different climatic regions. The total $\mathrm{N}$ in the soil was significantly higher at Terranora relative to other sites except East Palmerston (Table 4). Similarly, the ECEC, exchangeable $\mathrm{Mg}$ and exchangeable $\mathrm{Na}$ levels in the soil were greater than twice as high at Nambour relative to other locations (Table 4).

There were significant correlations amongst the chemical indicators. The ECEC was positively correlated with the soil $\mathrm{pH}$ $(r=0.66, \mathrm{P}<0.05)$, Ca $(r=0.89, \mathrm{P}<0.05), \mathrm{Mg}(r=0.80, \mathrm{P}<0.05)$ and $\mathrm{P}(r=0.60, P<0.05)$. The EC measured in the soil was negatively correlated to total $C(r=-0.80, P<0.05)$, labile $C$ $(r=-0.69, P<0.05)$ and total $\mathrm{N}(r=-0.80, P<0.05)$. However, EC was positively correlated with $\mathrm{P}(r=0.68, \mathrm{P}<0.05), \mathrm{K}$ $(r=0.60, \mathrm{P}<0.05)$ and $\mathrm{Na}(r=0.83, \mathrm{P}<0.05)$.

\subsection{Biological soil measurements}

Twenty-four different nematode taxa were identified in the survey. The total numbers of soil-dwelling nematodes were approximately twice as high in banana soils compared to soils from corresponding pasture or forest sites (Table 5). There was a 4.5 -fold increase in numbers of plant-parasitic nematodes under bananas relative to pastures or forest (Table 5). Helicotylenchus spp., Meloidogyne spp. and Rotylenchulus spp. were the dominant genera of plant-parasitic nematodes identified from soil samples. Furthermore, plant-parasitic nematodes comprised $80 \%$ of the total nematode number in the conventional banana production system, which contributed to a significantly lower diversity of nematodes in the conventional banana sites relative to forest and pasture sites (Table 5). Other plant-parasitic nematode nematodes identified in the different plant systems included Criconemella spp., Pratylenchus spp., Radopholus similis, Paratrichodorus spp. and Xiphenema spp. The pasture sites tended to have a greater number of Pratylenchus spp. (data not shown).

Bacterivores identified belonged to the families Acrobielidae, Cephalobidae, Pangrolaimidae, Prismatolaimidae, Rhabditidae and Wilsonemidae. The number of bacterivores was observed to be greatest in pasture systems and least in organic bananas (Table 5). The greatest number of fungivores (Aphelechidae and Aphelenchoididae) was also found at pasture sites, with the lowest number in conventional banana (Table 5). The organic banana sites had three times as many predatory nematodes (Monochidae and Tripylidae) as conventional banana sites (Table 5).

There were significantly higher numbers of plantassociated (Tylenchidae) and omnivorous nematodes (Dor-

Table 3 - Mean values and standard errors for selected soil chemical properties from paired sites comparing conventional banana production to less intensively managed vegetation systems

\begin{tabular}{|c|c|c|c|c|c|}
\hline & Conventional banana & Organic banana & Plant banana & Forest & Pasture \\
\hline Total organic C (\%) & $3.13 \pm 0.22^{\mathrm{a}}$ & $3.25 \pm 0.23$ & $2.59 \pm 0.26$ & $4.09 \pm 0.13$ & $4.26 \pm 0.29$ \\
\hline Labile C $\left(\mathrm{mg} \mathrm{g}^{-1}\right)$ & $2.61 \pm 0.23$ & $2.99 \pm 0.22$ & $3.17 \pm 0.39$ & $4.02 \pm 0.17$ & $3.96 \pm 0.43$ \\
\hline Total N (\%) & $0.25 \pm 0.03$ & $0.22 \pm 0.03$ & $0.16 \pm 0.02$ & $0.28 \pm 0.02$ & $0.32 \pm 0.02$ \\
\hline Total organic C/total $\mathrm{N}$ & $13.3 \pm 0.4$ & $16.1 \pm 1.4$ & $16.7 \pm 0.6$ & $15.9 \pm 1.0$ & $13.5 \pm 0.5$ \\
\hline Extractable $\mathrm{P}\left(\mathrm{mg} \mathrm{kg}^{-1}\right)$ & $163 \pm 19.3$ & $20 \pm 4.0$ & $17 \pm 4.9$ & $16 \pm 1.8$ & $84 \pm 21.8$ \\
\hline Exchangeable $\mathrm{K}\left(\mathrm{cmol}_{\mathrm{c}} \mathrm{kg}^{-1}\right)$ & $0.80 \pm 0.17$ & $0.25 \pm 0.02$ & $0.09 \pm 0.01$ & $0.42 \pm 0.05$ & $0.37 \pm 0.09$ \\
\hline Exchangeable $\mathrm{Ca}\left(\mathrm{cmol}_{\mathrm{c}} \mathrm{kg}^{-1}\right)$ & $8.78 \pm 0.76$ & $6.51 \pm 0.38$ & $12.00 \pm 1.41$ & $5.04 \pm 0.72$ & $5.27 \pm 1.13$ \\
\hline Exchangeable $\mathrm{Mg}\left(\mathrm{cmol}_{\mathrm{C}} \mathrm{kg}^{-1}\right)$ & $2.94 \pm 0.51$ & $2.25 \pm 0.22$ & $2.28 \pm 0.35$ & $2.72 \pm 0.17$ & $3.87 \pm 0.78$ \\
\hline Exchangeable $\mathrm{Na}\left(\mathrm{cmol}_{\mathrm{C}} \mathrm{kg}^{-1}\right)$ & $0.37 \pm 0.11$ & $0.14 \pm 0.03$ & $0.46 \pm 0.09$ & $0.18 \pm 0.03$ & $0.43 \pm 0.14$ \\
\hline Exchangeable $\mathrm{Al}\left(\mathrm{cmol}_{\mathrm{c}} \mathrm{kg}^{-1}\right)$ & $0.33 \pm 0.08$ & $1.63 \pm 0.67$ & $0.50 \pm 0.50$ & $1.14 \pm 0.28$ & $0.30 \pm 0.11$ \\
\hline Exchangeable $(\mathrm{H}+\mathrm{Al})\left(\mathrm{cmol}_{\mathrm{c}} \mathrm{kg}^{-1}\right)$ & $0.39 \pm 0.06$ & $1.57 \pm 0.54$ & 0.50 & $1.11 \pm 0.39$ & $0.37 \pm 0.09$ \\
\hline $\mathrm{pH}_{\mathrm{w}}$ & $6.20 \pm 0.18$ & $5.75 \pm 0.14$ & $6.35 \pm 0.21$ & $5.61 \pm 0.08$ & $5.65 \pm 0.13$ \\
\hline $\mathrm{pH}_{\mathrm{Ca}}$ & $5.59 \pm 0.15$ & $4.88 \pm 0.19$ & $5.96 \pm 0.28$ & $4.82 \pm 0.12$ & $4.97 \pm 0.13$ \\
\hline $\mathrm{EC}\left(\mathrm{dS} \mathrm{m} \mathrm{m}^{-1}\right)$ & $0.13 \pm 0.01$ & $0.06 \pm 0.01$ & $0.08 \pm 0.01$ & $0.07 \pm 0.01$ & $0.08 \pm 0.01$ \\
\hline $\operatorname{ECEC}\left(\mathrm{cmol}_{\mathrm{C}} \mathrm{kg}^{-1}\right)$ & $13.03 \pm 1.23$ & $9.79 \pm 0.44$ & $14.75 \pm 1.70$ & $9.18 \pm 0.59$ & $10.29 \pm 1.96$ \\
\hline pHBC $\left(\mathrm{cmol} \mathrm{H}^{+} \mathrm{kg}^{-1} \mathrm{pH}\right.$ unit $\left.^{-1}\right)$ & $7.03 \pm 0.68$ & $4.06 \pm 0.68$ & $3.28 \pm 0.79$ & $4.79 \pm 0.48$ & $4.25 \pm 0.43$ \\
\hline
\end{tabular}


Table 4 - Differences in soil chemical properties at different locations growing bananas to determine a minimum data set of soil health indicators

\begin{tabular}{|c|c|c|c|c|c|c|c|c|c|c|}
\hline \multirow[t]{2}{*}{ Site } & \multirow[t]{2}{*}{$\mathrm{pH}_{\mathrm{w}}$} & \multirow{2}{*}{$\begin{array}{c}\text { Total C } \\
(\%)\end{array}$} & \multirow{2}{*}{$\begin{array}{l}\text { Labile C } \\
\left(\mathrm{mg} \mathrm{g}^{-1}\right)\end{array}$} & \multirow{2}{*}{$\begin{array}{c}\text { Total N } \\
(\%)\end{array}$} & \multirow{2}{*}{$\begin{array}{c}\text { ECEC } \\
\left(\mathrm{cmol}_{\mathrm{c}} \mathrm{kg}^{-1}\right)\end{array}$} & \multicolumn{4}{|c|}{ Exchangeable nutrients $\left(\mathrm{cmol}_{\mathrm{c}} \mathrm{kg}^{-1}\right)$} & \multirow{2}{*}{$\begin{array}{c}\text { Extractable P } \\
-\left(\mathrm{mg} \mathrm{kg}^{-1}\right)\end{array}$} \\
\hline & & & & & & K & $\mathrm{Ca}$ & $\mathrm{Mg}$ & $\mathrm{Na}$ & \\
\hline East Palmerston & 5.15 n.s. & 4.53 n.s. & 3.43 n.s. & $0.37 \mathrm{~cd}$ & $1.59 \mathrm{a}$ & 0.81 n.s. & 4.84 n.s. & $1.59 \mathrm{ab}$ & $0.06 \mathrm{ab}$ & 126 n.s. \\
\hline Kennedy & 6.69 n.s. & 3.16 n.s. & 3.12 n.s. & $0.21 \mathrm{ab}$ & $2.13 \mathrm{a}$ & 0.64 n.s. & 7.38 n.s. & $2.13 \mathrm{ab}$ & $0.05 \mathrm{ab}$ & 30 n.s. \\
\hline Mission Beach & 6.06 n.s. & 6.62 n.s. & 3.30 n.s. & $0.27 \mathrm{bc}$ & $2.23 \mathrm{a}$ & 0.39 n.s. & 6.94 n.s. & $2.23 \mathrm{a}$ & $0.06 \mathrm{a}$ & 63 n.s. \\
\hline Tully & 6.55 n.s. & 3.57 n.s. & 4.13 n.s. & $0.22 \mathrm{ab}$ & $1.92 \mathrm{a}$ & 0.21 n.s. & 11.70 n.s. & $1.92 \mathrm{ab}$ & $0.09 \mathrm{ab}$ & 238 n.s. \\
\hline Nambour & 5.99 n.s. & 4.93 n.s. & 4.41 n.s. & $0.24 a b c$ & $7.65 \mathrm{c}$ & 0.16 n.s. & 6.70 n.s. & $7.65 d$ & $1.20 \mathrm{~d}$ & 66 n.s. \\
\hline Terranora & 6.04 n.s. & 3.06 n.s. & 2.67 n.s. & $0.45 \mathrm{~d}$ & $3.40 \mathrm{~b}$ & 1.08 n.s. & 5.81 n.s. & $3.40 \mathrm{c}$ & $0.50 \mathrm{c}$ & 80 n.s. \\
\hline Wamuran & 6.65 n.s. & 2.92 n.s. & 2.89 n.s. & $0.15 \mathrm{a}$ & $2.60 \mathrm{ab}$ & 0.19 n.s. & 6.41 n.s. & $2.60 \mathrm{bc}$ & $0.33 \mathrm{bc}$ & 12 n.s. \\
\hline
\end{tabular}

Means in columns with the same letters are not significantly different at $P<0.05 ;$ n.s. denotes no significant difference.

Table 5 - Soil nematode total abundance, trophic groups (nematodes $100 \mathrm{~g}^{-1}$ soil) and nematode indices comparing conventional banana production to less intensively managed vegetation systems

\begin{tabular}{|c|c|c|c|c|c|}
\hline & Conventional banana & Organic banana & Plant banana & Forest & Pasture \\
\hline \multicolumn{6}{|c|}{ Nematodes $100 \mathrm{~g}^{-1}$ soil } \\
\hline Total nematode & $1070 \pm 219^{a}$ & $531 \pm 199$ & $377 \pm 107$ & $453 \pm 61$ & $693 \pm 82$ \\
\hline Plant-parasites & $870 \pm 208$ & $372 \pm 175$ & $73 \pm 15$ & $131 \pm 30$ & $193 \pm 53$ \\
\hline Plant-associated & $26 \pm 11 \mathrm{a}$ & $31 \pm 17 \mathrm{ab}$ & $104 \pm 37 b c$ & $49 \pm 5 a b$ & $156 \pm 34 b$ \\
\hline Fungivores & $16 \pm 5$ & $31 \pm 6$ & $37 \pm 19$ & $51 \pm 9$ & $63 \pm 15$ \\
\hline Bacterivores & $118 \pm 33$ & $42 \pm 11$ & $74 \pm 18$ & $149 \pm 36$ & $169 \pm 18$ \\
\hline Predators & $11 \pm 5$ & $33 \pm 9$ & $32 \pm 22$ & $21 \pm 4$ & $18 \pm 6$ \\
\hline Omnivores & $29 \pm 7 a$ & $22 \pm 6 a$ & $56 \pm 36 a b$ & $52 \pm 8 \mathrm{a}$ & $94 \pm 13 b$ \\
\hline \multicolumn{6}{|l|}{ Nematode indices } \\
\hline Diversity $H$ & $1.40 \pm 0.10 \mathrm{a}$ & $1.61 \pm 0.13 \mathrm{ab}$ & $1.74 \pm 0.08 \mathrm{ab}$ & $2.12 \pm 0.07 b$ & $1.97 \pm 0.04 b$ \\
\hline Dominance $\lambda$ & $0.26 \pm 0.03$ & $0.29 \pm 0.04$ & $0.21 \pm 0.02$ & $0.16 \pm 0.02$ & $0.19 \pm 0.01$ \\
\hline $\mathrm{B}: \mathrm{F}$ ratio & $0.86 \pm 0.02$ & $0.55 \pm 0.09$ & $0.75 \pm 0.13$ & $0.65 \pm 0.06$ & $0.75 \pm 0.03$ \\
\hline Enrichment index & $55 \pm 6$ & $29 \pm 7$ & $19 \pm 12$ & $50 \pm 5$ & $40 \pm 7$ \\
\hline Structure index & $60 \pm 6$ & $76 \pm 6$ & $69 \pm 13$ & $77 \pm 4$ & $74 \pm 4$ \\
\hline Channel index & $26 \pm 7$ & $81 \pm 13$ & $50 \pm 50$ & $47 \pm 9$ & $51 \pm 11$ \\
\hline
\end{tabular}

Means in rows with the same letters are not significantly different at $P<0.05$.

a Standard error values.

ylaimidae and Noriidae) in the pasture system relative to conventional bananas (Table 5). Numbers of omnivorous nematodes were positively correlated with the total $\mathrm{C}$ and labile $C$ measurements ( $r=0.65$ and 0.63 , total $C$ and labile $C$, respectively, $P<0.05)$. Conversely, the number of omnivorous nematodes was negatively correlated with soil bulk density in the $0-5 \mathrm{~cm}$ layer $(r=-0.72, P<0.05)$. The diversity of nematodes in the soil was positively correlated with total C $(r=0.52, P<0.05)$, labile C $(r=0.58, P<0.05)$, and the number of predatory $(r=0.65, P<0.05)$ and omnivorous nematodes $(r=0.64, P<0.05)$. Furthermore, EC measurements in the soil were positively correlated with plantparasitic nematode numbers $(r=0.59 \mathrm{P}<0.05)$, the nematode indices B:F ratio $(r=0.66 P<0.05)$, nematode dominance index $(r=0.66 \mathrm{P}<0.05)$ and negatively with the channel index $(r=-0.64 \mathrm{P}<0.05)$.

Between sampling locations there was a significantly lower enrichment index at Nambour and Wamuran relative to the four north Queensland locations (Table 6). Conversely, there was a significantly, lower structure index at East Palmerston and Kennedy relative to Nambour and Wamuran (Table 6).

A multivariate cluster analysis of the composition of nematode trophic groups from Table 5 was able to discriminate between sites based on their vegetation type (Fig. 3). Plant systems were grouped into three categories using cluster analysis at a Euclidean similarity of greater than 0.85 (Fig. 3). One group contained all banana sites, regardless of management type, conventional or organic, except the newly planted banana crop at Wamuran. However, this group also included the forest soil from Tully (Fig. 3). A second group contained five of the less intensely managed systems, pasture or rainforest, but also included the newly planted banana crop at Wamuran. The nematode community from the forest soil at Wamuran

\begin{tabular}{|c|c|c|}
\hline Location & Enrichment index & Structure index \\
\hline East Palmerston & $57.0 \mathrm{~b}$ & $55.8 \mathrm{a}$ \\
\hline Kennedy & $73.1 \mathrm{bc}$ & $55.7 \mathrm{a}$ \\
\hline Mission Beach & $72.2 \mathrm{c}$ & $80.5 \mathrm{~b}$ \\
\hline Tully & $76.6 \mathrm{c}$ & $72.5 \mathrm{ab}$ \\
\hline Nambour & $29.1 \mathrm{a}$ & $87.4 \mathrm{~b}$ \\
\hline Wamuran & $14.8 \mathrm{a}$ & $75.0 \mathrm{~b}$ \\
\hline
\end{tabular}

Means in columns with the same letters are not significantly different at $P<0.05$. 


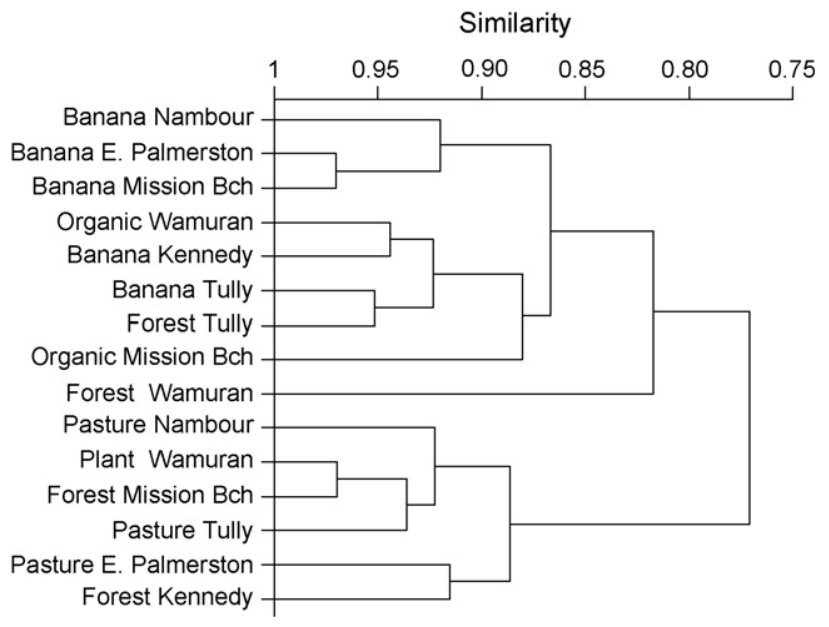

Fig. 3 - Multivariate cluster analysis dendrogram of the similarities of soil nematode trophic composition at seven locations comparing conventional banana production to less intensively managed vegetation systems.

did not have a nematode community composition similar to either group (Fig. 3).

\section{Discussion}

No single indicator was universal in describing soil property changes due to the cultivation of bananas relative to less intensive vegetation systems. However, there was a significant correlation between soil physical, chemical and biological indicators, which validates the holistic approach to soil health management and the need to better understand the flow-on effects of soil management decisions. Based on the results from this survey, a set of soil health indicators was developed (Table 7). This list is not exhaustive, nor meant to be prescriptive, but includes the indicators that meet the criteria listed by Doran and Safley (1997), in particular, being sensitive to changes in soil management and integrating soil physical, chemical and biological properties. Banana growers are able to use the indicators to determine if changes in land management practices, such as reduced fertiliser inputs, minimum tillage land preparation, vegetating interrow spaces and use of organic amendments, are having a positive impact on soil health.

Total carbon and labile carbon were the most sensitive chemical measurements to changes in land use management. A 33\% reduction in the total $\mathrm{C}$ and $50 \%$ reduction in labile $\mathrm{C}$ under conventional bananas relative to forest sites indicated that conventional banana soil management techniques had reduced the soil carbon resource. Soil $\mathrm{C}$ has a crucial role in aggregate stability, nutrient recycling and soil chemical properties (Moody et al., 1997; Oades, 1984; Stine and Weil, 2002). There is a strong correlation between total and labile $C$ and aggregate stability, highlighting the importance of preserving soil $\mathrm{C}$ to maintain soil integrity, improve drainage and to minimise soil erosion (Oades, 1984; Stine and Weil, 2002). Therefore, a measurement of soil $C$ should be included in the minimum data set of soil health indicators due to its sensitivity to changes in soil management and its relationship to other soil properties. The use of soil $\mathrm{C}$ measurements has been included in a number of soil health monitoring data sets (Lilburne et al., 2004; McKenzie and Dixon, 2006). The method proposed by Weil et al. (2003) would be a useful measure as it

Table 7 - A proposed minimum set of soil measurements that were responsive to changes in vegetation or soil management and related to other soil properties for use in the Queensland banana industry

Soil indicator

Justification for inclusion in a minimum data set

Physical soil properties
Silt
Clay
Bulk density
Chemical soil indicators
Total C
Labile C
pH
EC
Total N
Colwell P
ECEC
Biological soil indicators
Nematode community analysis:
Diversity
Enrichment index
Structure index
B:F ratio
Trophic groups

Validation of soil type similarity

Validation of soil type similarity

Soil compaction, relationship to other soil properties

Response to changes to soil management, related to other soil measurements

Response to changes to soil management, related to other soil measurements

Ease of measurement

Ease of measurement, related to other soil measurements Changes in site properties, related to other soil properties Availability of nutrients, response to fertiliser use Ability of soil to hold onto nutrients, summarises nutrient supplying capacity of soils.

Biological soil processes, relationship to chemical and physical properties 
allows in-field determination of labile C. We are currently validating this method against laboratory measures of soil C.

The organic banana production systems investigated in this survey were able to preserve more soil $\mathrm{C}$ relative to conventional bananas. Under organic bananas, the total and labile $\mathrm{C}$ exhibited similar levels to those in forest and pasture soils (Fig. 2). Furthermore, calculation of C:N ratios revealed that organic banana production had a higher $\mathrm{C}: \mathrm{N}$ ratio relative to conventional banana production (Table 3), supporting the hypothesis that organic banana production techniques reduce the rate of $\mathrm{N}$ mineralisation, thus reducing the risk of off-site nitrate movement and maximising the opportunity for $\mathrm{N}$ uptake by the crop. The management techniques used by organic banana farmers need further investigation to determine which practices, such as retention of crop residues, reduced tillage and reduced use of nitrogenous fertilisers are able to conserve and sequester soil $C$. These may then be integrated into conventional farming practices.

Analysis of the nematode community using a cluster analysis dendrogram revealed less than $85 \%$ similarity in the composition of the nematode community under banana production relative to the other plant systems of forest or pasture, regardless of the location sampled (Fig. 3). This indicates that the plant community and its management have a large impact on the soil biota, as suggested by Wardle et al. (2004). Soil in long-term banana monocultures is dominated by banana roots, giving a low diversity of root systems in the soil. This would be expected to select organisms adapted to survive in and around the banana root rhizosphere. The trophic composition of the nematode community under bananas did not respond to the management differences between organic or conventional systems, which suggested that plant species composition has a greater impact on nematode communities than crop management. This is in contrast with other research findings that suggest organic agriculture changes soil biological properties (Berkelmans et al., 2003; Bulluck et al., 2002; Gunapala and Scow, 1998), but in agreement with the findings of Neher (1999a,b) that organic sites are not good reference sites for comparing farm management practices because of the potential crop influence.

The newly planted banana crop at Wamuran had a nematode community composition with less than $85 \%$ similarity to other banana crops (Fig. 3). This perhaps reflected the short length of time that the crop had been established and growth of weeds around the banana plants. A plant crop of bananas does not have the same canopy cover and therefore allows more weed competition, which breaks the root monoculture below the soil surface. Also, establishment of bananas in sub-tropical production areas of Queensland leaves large areas of soil undisturbed, which may result in soil biology remaining unchanged until banana plants are well established.

The structure and enrichment indices proposed by Ferris et al. (2001) were not sensitive to significant changes in either plant systems or management in this survey. However, they were able to indicate differences between locations due to soil type and climate (Table 6). Neher et al. (2005) similarly found that nematode indices were inconsistent among ecosystems in their ability to distinguish levels of disturbance, when comparing wetlands, forests and agricultural soils.
The north Queensland sites (East Palmerston, Kennedy, Mission Beach and Tully) had significantly higher enrichment indices relative to the southeast Queensland sites (Table 6). This suggested that there were more resources available to the soil food web in north Queensland relative to south-east Queensland. This may reflect climatic differences (higher rainfall and soil temperatures in north Queensland) leading to greater biological activity and nutrient recycling in the soil.

The structure index, a measure of the number of trophic layers in the soil nematode food web and the potential for regulation by predators (Ferris et al., 2001) was significantly higher at the Mission Beach, Nambour and Wamuran locations relative to East Palmerston and Kennedy (Table 6). This suggested greater soil disturbance at Kennedy and East Palmerston, which tends to simplify the soil food web. Interestingly, the pasture at East Palmerston and forest site at Kennedy had a $90 \%$ similarity in nematode trophic group composition (Fig. 3), which may represent a similar level of disturbance in the soil nematode communities. The high structure index at Wamuran and Mission Beach may reflect the impact of organic banana management increasing the average structure index for these sites relative to conventional bananas (Table 6).

The bulk density in the top $5 \mathrm{~cm}$ at the forest sites in north Queensland was generally less than that found at greater depths, to $20 \mathrm{~cm}$ (Table 2). The lower bulk density in the top $5 \mathrm{~cm}$ did not occur in the banana sites (Table 2). In general, there was an increase in bulk density at the banana sites ranging from 11 to $18 \%$ relative to the forest sites. Increasing soil bulk density was negatively correlated to labile $\mathrm{C}$, total C and total N. Furthermore, the number of omnivorous nematodes was negatively correlated with increasing soil bulk density in the $0-5 \mathrm{~cm}$ layer, which suggested that an unfavourable habitat may have developed in soils with high soil bulk density. Although, bulk density can be influenced by soil texture, the soil types at each paired site were not greatly different, with the exception of Mission Beach and Nambour. However, across the soil types used in banana production in Australia, bulk density appeared to be related to a range of soil properties, such as total and labile $\mathrm{C}$ and total $\mathrm{N}$, justifying its inclusion as a soil health indicator.

The EC measured in conventional banana soils was double that in organic banana soil, 1.8 times higher than in forest soils and 1.6 times higher than in pasture soils (Table 3). EC was associated with a number of chemical and physical soil properties. EC has generally been used to measure soil salinity and, accordingly, there was a significant correlation between exchangeable Na and EC $(r=0.83 P<0.05)$. However, electrical conductivity can also serve as a measure of soluble nutrients (Smith and Doran, 1996). EC measures were positively corelated with exchangeable $\mathrm{K}$ and extractable $\mathrm{P}$, both nutrients recording the highest levels in conventional banana soils. Factors affecting EC values in intensively managed agriculture can also impact on microbial processes (Neher et al., 2005; Smith and Doran, 1996). The associations between EC and the nematode community indices suggested that factors leading to increased EC tend to favour a more bacterially dominated soil biology, with less diversity. This may be because the highest EC measurements were recorded in banana monocultures, which favour a greater proportion of 
plant-parasitic nematodes and have a higher nutrient enrichment due to fertiliser use. It is possible that management practices contributing to higher soil EC and extractable $\mathrm{P}$, such as high fertiliser usage, may contribute to the decline in predatory nematode populations. EC, as a soil indicator, has been found to be related to changes in the soil nematode communities in different land uses in North Carolina (Neher et al., 2005). The use of EC as a soil health indicator appears to be justified due to its simplicity of measurement and its association with other chemical and biological properties.

The development of a minimum set of indicators for soil health measurements should include soil physical, chemical and biological measurements. The measurements most responsive to changes following banana cultivation are listed in Table 7. However, there is a lack of credible biological indicators, even though the importance of soil biological measurements is well recognised (Coleman et al., 2004; Doran and Jones, 1996; Pankhurst et al., 1997). The development of BIOLOG ${ }^{\circledR}$ metabolic assays and the use of 16 sRNA techniques have proved useful in other studies to discriminate between soil management impacts on the biological community (Bending et al., 2004; Crecchio et al., 2004; Schutter et al., 2001). However, these techniques are not able to be used in the field as they require microbiological knowledge and specialised equipment. Analysis of the soil nematode community offered some insights into the soil microbial processes and was related to soil physical and chemical properties. However, more work must occur in this area to determine whether these biological indicators can be made sufficiently responsive and relevant to the Australian banana industry.

\section{Conclusion}

The conventional cultivation of bananas in Australia has altered the physical, chemical and biological soil properties. For the banana industry to remain sustainable there must be improvements in soil management. By determining the soil properties have that had changed under banana cultivation, the Australian banana industry has a tool to assess changes in crop management allowing the integration of productivity with environmental stewardship. Although, it would never be possible to return the soil to the original condition, the measurement of soil properties in less intensively managed plant system provides a bench mark for comparison. The set of holistic soil health indicators, developed in this study, will help the Australian banana industry to quantify the impact of farm practices and promote more sustainable practices for the future.

\section{Acknowledgements}

We gratefully acknowledge the landholders who took part in this survey: Mr. Geoff. Bush, Mr. Darryl Wall, Mr. Patrick Leahy, Mr. Maurice Franklin, Mr. Ian Barnes, Mr. Ted Bear, Mr. Ross Lindsay and Mr. Andrew Want. We would also like to thank Ms. Tracy Whiteing and Mr. Dale Heiner who assisted with the sampling and processing of soil samples. Funding for this study was provided by Growcom (formerly Queensland Fruit and
Vegetable Growers) Banana Special Interest Group, Horticulture Australia Limited, Department of Primary Industries and Fisheries, Queensland and Department of Natural Resources, Mines and Water, Queensland under project FR02025.

\section{R E F E R E N C E S}

Aitken, R.L., Moody, P.W., 1994. The effect of valence and ionic strength on the measurement of $\mathrm{pH}$ buffer capacity. Aust. J. Soil Res. 32, 975-984.

Andrews, S.S., Karlen, D.L., Cambardella, C.A., 2004. The soil management assessment framework: a quantitative soil quality evaluation method. Soil Sci. Soc. Am. 68, 1945-1962.

Anon., 2003. Reef Water Quality Protection Plan. Queensland Government, Department of the Premier and Cabinet, Brisbane Queensland, 44 pp. Available at http:// www.reefplan.qld.gov.au (verified March 27, 2008).

Bending, G.D., Turner, M.K., Rayns, F., Marx, M.-C., Wood, M., 2004. Microbial and biochemical soil quality indicators and their potential for differentiating areas under contrasting agricultural management regimes. Soil Biol. Biochem. 36, 1785-1792.

Berkelmans, R., Ferris, H., Tenuta, M., van Bruggen, A.H.C., 2003. Effects of long-term crop management on nematode trophic levels other than plant feeders disappear after 1 year of disruptive soil management. Appl. Soil Ecol. 23, 223-235.

Bongers, T., 1990. The maturity index: an ecological measure of environmental disturbance based on nematode species composition. Oecologia 83, 14-19.

Bulluck III, L.R., Brosius, M., Evanylo, G.K., Ristiano, J.B., 2002. Organic and synthetic fertility amendments influence soil microbial, physical and chemical properties on organic and conventional farms. Appl. Soil Ecol. 19, 147-160.

Coleman, D.C., Crossley, D.A., Hendrix, P.F., 2004. Fundamentals of Soil Ecology, 2nd ed. Elsevier Academic Press, Boston MA, pp. 385.

Collins, D., Cirillo, L., Abraham, L., 2004. The Australian Horticulture Statistics Handbook. Horticulture Australia Limited, Sydney, Australia.

Colwell, J.D., 1963. The estimation of phosphorus fertiliser requirements of wheat in southern New South Wales by soil analysis. Aust. J. Exp. Agric. Anim. Husb. 6, 105-120.

Crecchio, C., Gelsomino, A., Ambrosoli, R., Minati, J.L., Ruggiero, P., 2004. Functional and molecular responses of soil microbial communities under differing soil management practices. Soil Biol. Biochem. 36, 1873-1883.

Doran, J.W., Jones, A.J., 1996. Methods for Assessing Soil Quality. Soil Science Society of America, Madison, WI, pp. 410.

Doran, J.W., Safley, M., 1997. Defining and assessing soil health and sustainable productivity. In: Pankhurst, C.E., Doube, B.M., Gupta, V.V.S.R. (Eds.), Biological Indicators of Soil Health. CABI Publishing, Wallingford, UK, pp. 1-28.

Ferris, H., Bongers, T., de Goede, R.G.M., 2001. A framework for soil food web diagnostics: extension of the nematode faunal analysis concept. Appl. Soil Ecol. 18, 13-29.

Glover, J.D., Reganold, J.P., Andrews, P.K., 2000. Systematic method for rating soil quality of conventional, organic, and integrated apple orchards in Washington State. Agric. Ecosyst. Environ. 80, 29-45.

Gunapala, N., Scow, K.M., 1998. Dynamics of soil microbial biomass and activity in conventional and organic farming systems. Soil Biol. Biochem. 30, 805-816.

Gupta, V.V.S.R., Yeates, G.W., 1997. Soil microfauna as bioindicators of soil health. In: Pankhurst, C.E., Doube, 
B.M., Gupta, V.V.S.R. (Eds.), Biological Indicators of Soil Health. CABI Publishing, Wallingford, UK, pp. 201-233.

Hohberg, K., 2003. Soil nematode fauna of afforested mine sites: genera distribution, trophic structure and functional guilds. Appl. Soil Ecol. 22, 113-126.

Isbell, R.F., 1996. The Australian Soil Classification. CSIRO Publishing, Melbourne, Australia.

Karlen, D.L., Ditzler, C.A., Andrews, S.S., 2003. Soil quality: why and how? Geoderma 114, 145-156.

Kleiese, Y., Prove, B., McShane, T., Moody, P., Reghenzani, J., 1997. Nutrient Loss Study in the Johnstone River Catchment. Queensland Department of Primary Industries, Brisbane.

Lilburne, L., Sparling, G.P., Schipper, L.A., 2004. Soil quality monitoring in New Zealand: development of an interpretive framework. Agric. Ecosyst. Environ. 104, 535-544.

McKenzie, N.J., Dixon, J., 2006. Monitoring Soil Condition Across Australia: Recommendations from the Expert Panels. National Land and Water Resource Audit, Australian Government, Canberra, Australia.

Moody, P.W., Aitken, R.L., 1997. Soil acidification under some tropical agricultural systems. 1. Rates of acidification and contributing factors. Aust. J. Soil Res. 35, 163-173.

Moody, P.W., Yo, S.A., Aitken, R.L., 1997. Soil organic carbon, permanganate fractions, and the chemical properties of acidic soils. Aust. J. Soil Res. 35, 1301-1308.

Neher, D.A., 1999a. Nematode communities in organically and conventionally managed agricultural soils. J. Nematol. 31, 142-154.

Neher, D.A., 1999b. Soil community composition and ecosystem processes. Agroforest. Syst. 45, 159-185.

Neher, D.A., 2001. Role of nematodes in soil health and their use as indicators. J. Nematol. 33, 161-168.

Neher, D.A., Campbell, C.L., 1994. Nematode communities and microbial biomass in soils with annual and perennial crops. Appl. Soil Ecol. 1, 17-28.

Neher, D.A., Wu, J., Barbercheck, M.E., Anas, O., 2005. Ecosystem type affects interpretation of soil nematode community measures. Appl. Soil Ecol. 30, 47-64.

Neilsen, M.N., Winding, A., 2002. Microorganisms as Indicators of Soil Health. National Environment Research Institute, Denmark, Technical Report No. 388, Denmark.
Oades, J.M., 1984. Soil organic matter and structural stability: mechanisms and implications for management. Plant Soil 76, 319-337.

Pankhurst, C.E., Doube, B.M., Gupta, V.V.S.R., 1997. Biological Indicators of Soil Health. CAB International, Wallingford, UK.

Rayment, G.E., Higginson, F.R., 1992. Australian Laboratory Handbook of Soil and Water Chemical Methods. Inkata Press, Sydney, Australia.

Sanchez, P.A., Palm, C.A., Buol, S.W., 2003. Fertility capability soil classification: a tool to help assess soil quality in the tropics. Geoderma 114, 157-185.

Schloter, M., Dilly, O., Munch, J.C., 2003. Indicators for evaluating soil quality. Agric. Ecosyst. Environ. 98, 255-262.

Schutter, M.E., Sandeno, J.M., Dick, R.P., 2001. Seasonal, soil type, and alternative management influences on microbial communities of vegetable cropping systems. Biol. Fertil. Soils 34, 397-410.

Smith, J.L., Doran, J.W., 1996. Measurement and use of $\mathrm{pH}$ and electrical conductivity for soil quality analysis. In: Doran, J.W., Jones, A.J. (Eds.), Methods for Assessing Soil Quality. Soil Science Society of America, Madison, WI, pp. 169-185.

Stine, M.A., Weil, R.R., 2002. The relationship between soil quality and crop productivity across three tillage systems in south central Honduras. Am. J. Alt. Agric. 17, 2-8.

Wardle, D.A., Bardgett, R.D., Klironomos, J.N., Setala, H., van der Putten, W.H., Wall, D.H., 2004. Ecological linkages between aboveground and below ground biota. Science 304, 1629-1633.

Weil, R.R., Islam, K.R., Stine, M.A., Gruver, J.B., Samson-Liebig, S.E., 2003. Estimating active carbon for soil quality assessment: a simplified method for laboratory and field use. Am. J. Alt. Agric. 18, 3-17.

Whitehead, A.G., Hemming, J.R., 1965. A comparison of some quantitative methods extracting small vermiform nematodes from the soil. Ann. Appl. Biol. 55, 25-38.

Yeates, G.W., 2003. Nematodes as soil indicators: functional and biodiversity aspects. Biol. Fertil. Soils 37, 199-210.

Yeates, G.W., Bongers, T., 1999. Nematode diversity in agroecosystems. Agric. Ecosyst. Environ. 74, 113-135.

Yeates, G.W., Bongers, T., De Goede, R.G.M., Freckman, D.W., Georgieva, S.S., 1993. Feeding habits in soil nematode families and genera-an outline for soil ecologists. J. Nematol. 25, 315-331. 